\title{
Storage of Lyophilized Cultures of Lactobacillus bulgaricus under different relative humidities and atmospheres
}

\begin{abstract}
The viability of lyophilized cultures of Lactobacillus bulgaricus in skim milk, during storage at different temperatures, relative humidities, and atmospheres was investigated. Survival was greatest at $11 \%$ relative humidity and at $5{ }^{\circ} \mathrm{C}$. Indirect and direct evidence is presented supporting the hypothesis that membrane damage occurs during storage. Experiments on the lipid composition of the cell membrane demonstrate that changes occur with time that are probably the result of oxidation. A study on the li!pid composition of the cell membrane by gas chromatography showed that the unsaturated/saturated fatty acid index changes with time during storage.
\end{abstract}

\section{Introduction}

Dairy starter cultures are now available in frozen or freeze-dried forms. The main advantages of dry cultures over the frozen ones are that they are easier to handle and store. Freeze-dried cultures are produced when the organism is dried in the frozen state.

It has been observed that the process of freezing and drying can damage the bacterial cell membrane (Sinskey 1971) but the damage can be minimised with the addition of certain agents prior to treatment, like milk, that prevent cellular injury by stabilising the cell membrane constituents during the preservation procedures (Morich 1974). The major problem after freeze-drying, is the loss of viability that can be observed during storage, especially in the case of dry cultures kept at room temperature (Champagne et al. 1991).

Many authors have reported on the adverse effect of oxygen on survival in the freeze-dried form (Naylor and

H. P.Castro · P. M. Teixeira · R. Kirby $(\square)$

Escola Superior de Biotecnologia,

R. Dr. Antonio Bernardino Almeida,

A-100 Porto, Portugal.

Fax: 3512590351
Smith 1946; Lion 1963; Israeli and Kohn 1972). Previous studies on the effect of anti-oxidants on survival of Lactococcus lactis have demonstrated their positive effects in the suspending medium (Couture and Gagné 1991). However, to date no papers have been published identifying which bacterial cellular components are in fact oxidised. In living organisms lipids and particularly the methylene-interrupted polyunsaturated fatty acids, components of cell membranes, are described as being extremely subject to oxidation (Pryor 1971) leading to a disruption of membrane structure and function (Girotti and Thomas 1984).

The purpose of this work was to examine the behaviour of Lactobacillus bulgaricus during lyophilized storage in order to identify the reasons for loss of viability. This work takes on more importance as the industry moves in the direction of using modified forms of lactic acid bacteria, and the maintenance of the desirable traits during storage is essential. The research evaluated the role of temperature, relative humidity and atmosphere composition in relation to the survival of dried cultures of the bacteria in skim milk powder during storage.

\section{Materials and methods}

Organism

Lactobacillus delbrueckii ssp. bulgaricus NCFB 1489 was used throughout the study. The original reference cultures were maintained in cryogenic storage at $-80^{\circ} \mathrm{C}$ on glass beads. Working cultures were maintained as stabs on MRS agar ( $\mathrm{Lab} \mathrm{M}$ ) at $4^{\circ} \mathrm{C}$. Stabs were prepared from cultures grown at $37^{\circ} \mathrm{C}$ for $24 \mathrm{~h}$ aerobically in a shaking water bath. Fresh stabs were prepared from working cultures every month. New working cultures were prepared from the original reference culture every 3 months.

Media

Unless otherwise stated, all media were prepared according to the manufacturers' instructions. The growth media used in this study 
were Man Rogosa and Sharpe broth (De Man et al. 1964) (MRS) and MRS agar from Lab M.

The diluent phosphate buffer was prepared by mixing $0.01 \mathrm{~mol} / \mathrm{l}$ $\mathrm{K}_{2} \mathrm{HPO}_{4}$ (Merck, Frankfurt, Germany) and $0.01 \mathrm{~mol} / 1 \mathrm{KH}_{2} \mathrm{PO}_{4}$ (Merck), dissolving both in a solution of $0.15 \mathrm{~mol} / 1 \mathrm{NaCl}$ (Merck), adjusting the $\mathrm{pH}$ to $7.0 \pm 0.1$ and sterilizing.

\section{Culture preparation}

To ensure culture homogeneity between experiments and to model industrial protocols the following procedure was used. Samples of $10 \mathrm{ml}$ of MRS broth were inoculated from the MRS/agar stabs and incubated for $24 \mathrm{~h}$ at $37^{\circ} \mathrm{C}$, with gentle shaking. This first broth was subsequently subcultured into a second MRS broth $(1 \%, v / v)$ and incubated as before. This broth was then used to inoculate 11 of a third MRS broth $(1 \%, v / v)$. The cultures were incubated at $37^{\circ} \mathrm{C}$ for $16 \mathrm{~h}$ and agitated using magnetic stirrer bars to produce earlystationary-phase cells. Cells were harvested by centrifugation at $16000 \mathrm{~g}$ at $4^{\circ} \mathrm{C}$ and washed twice with cold phosphate buffer ( $\mathrm{pH} 7.0)$ before suspension in skim milk (Lab M) $(11 \%, \mathrm{w} / \mathrm{v})$ at a concentration of approximately $10^{9} \mathrm{cells} / \mathrm{ml}$ for lyophilization.

\section{Lyophilization}

Samples were first frozen at $-80^{\circ} \mathrm{C}$ in a deep-freeze and then desiccated under vacuum $(6.7 \mathrm{~Pa})$ in the freeze-drier (Martin Christ Alpha 1-4) for $24 \mathrm{~h}$.

Effect of relative humidity

After freeze-drying, samples were equilibrated in hermetically-sealed flasks containing saturated salt solutions of lithium chloride, potassium acetate, magnesium chloride or sodium chloride giving equilibrium relative humidities $\left(\mathrm{RH}_{\mathrm{eq}}\right)$ of $11 \%, 23 \%, 33 \%$ and $75 \%$ respectively. Saturated solutions of sodium bromide provided a $\mathrm{RH}_{\mathrm{eq}}$ of $63 \%$ or $59 \%$ depending on the temperature. Relative humidity of $0 \%$ was achieved by equilibrating over phosphorus pentoxide. Flasks were held at either $20^{\circ} \mathrm{C}$ or $5{ }^{\circ} \mathrm{C}$ during the study. Samples were removed at intervals for counting.

\section{Effect of atmosphere}

After freeze-drying, samples were introduced into hermeticallysealed jars over phosphorus pentoxide $\left(\mathrm{RH}_{\mathrm{eq}} 0 \%\right)$. The jars were flushed twice with nitrogen or oxygen, evacuated again and sealed under nitrogen or oxygen at $20^{\circ} \mathrm{C}$. Samples were taken at intervals and the above procedure repeated

\section{Enumeration}

Prior to plating, samples were rehydrated with sterile distilled water at room temperature $\left(20^{\circ} \mathrm{C}\right)$ and immediately agitated. Viability was determined immediately after freeze-drying and at intervals during storage, on solid media by the Miles and Misra technique (1936). Plates were incubated at $37^{\circ} \mathrm{C}$ for $48 \mathrm{~h}$ before counting.

\section{Detection of injured organisms}

Selective media for the detection of sublethally injured organisms were as follows: MRS agar plus $\mathrm{NaCl}(6.25 \mathrm{mg} / \mathrm{ml})$, MRS agar plus chloramphenicol $(0.313 \mu \mathrm{g} / \mathrm{ml})$, and MRS agar plus pyronin $\mathrm{Y}(5$ $\mu \mathrm{g} / \mathrm{ml}$ ). Each agent was made up fresh and sterilized by filtration (membrane filter pore size $0.22 \mu \mathrm{m}$ ). Each selective agent was used at the minimum inhibitory concentration previously determined. MRS agar was prepared as above, sterilized and cooled to $50^{\circ} \mathrm{C}$ before selective agents were added prior to distribution into petri dishes.

\section{Analysis of data}

Data were analysed by standard analysis of variance using the StatView SE and Graphics (Abacus Concepts Inc., Berkeley, Calif.) packages. Unless otherwise noted, significance is expressed at a probability $(P)$ of 0.05 , or less.

\section{Lipid composition}

During storage at different water activities, membrane lipids were analysed by gas-liquid chromatography by the method of Rozès et al. (1993). Methanolysis of cell materials was carried out with sodium methoxide $(1 \mathrm{M})$ in methanol. Fatty acid methyl esters were extracted with hexane, and their retention times were compared with known standards obtained from Sigma. The total peak areas of the main fatty acids present: cyclopropane, palmitoleic, stearic, palmitic and oleic acids, were used to determine the relative percentage of each fatty acid present, and for calculation of the ratio of unsaturated to saturated fatty acids.

\section{Results}

The survival curves of freeze-dried $L$. bulgaricus stored at various relative humidities are shown in Figs. 1, 2 at $5^{\circ} \mathrm{C}$ and Fig. 3 at $20^{\circ} \mathrm{C}$.

Higher survival rates with time were found upon storage of lyophilized cultures under refrigeration. At both temperatures survival was strongly dependent on the relative humidity at which samples were stored. At $20^{\circ} \mathrm{C}$ the greatest decrease in the number of viable cells was found in the sample stored at $59 \% \mathrm{RH}_{\mathrm{eq}}$ and the smallest decrease in those samples stored at $11 \%$ and $23 \%$ of $\mathrm{RH}_{\text {eq. }}$. Although the loss in viability observed at $5^{\circ} \mathrm{C}$ was less than at $20^{\circ} \mathrm{C}$ for all relative humidities

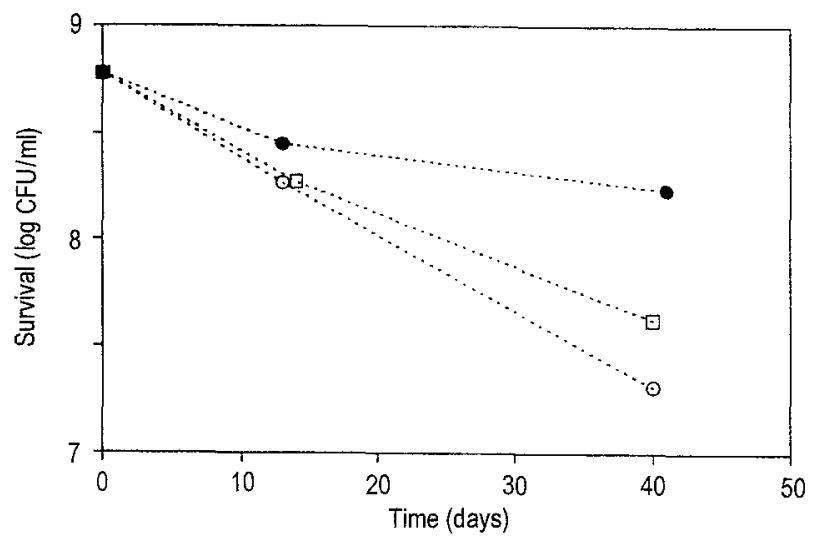

Fig. 1 Survival $(\mathrm{cfu} / \mathrm{ml})$ of freeze-dried L. bulgaricus at $5^{\circ} \mathrm{C}$ as a function of relative humidity: $\bigcirc 0 \%, 11 \%, \square 33 \%$ 


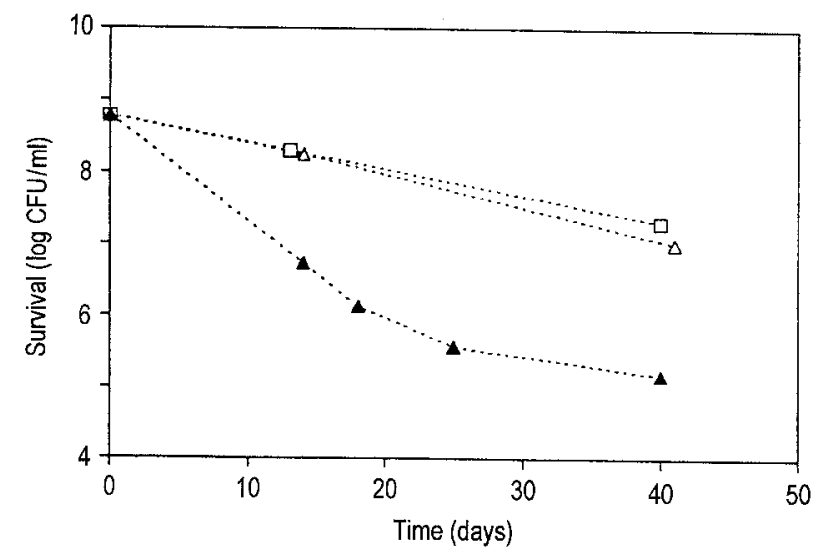

Fig. 2 Survival $(\mathrm{cfu} / \mathrm{m} 1)$ of freeze-dried L. bulgaricus at $5^{\circ} \mathrm{C}$ as a function of relative humidity: $\square 23 \%, \triangle 63 \%, \wedge 75 \%$

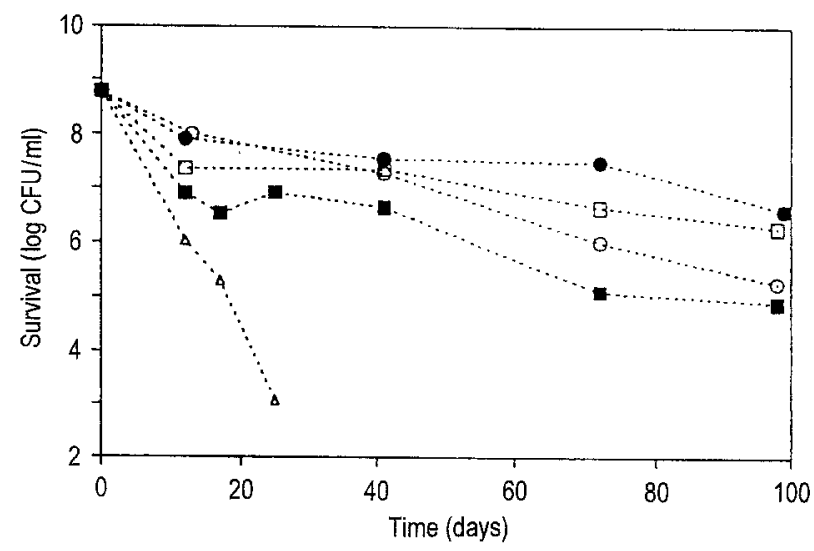

Fig. 3 Survival of freeze-dried L. bulgaricus at $20^{\circ} \mathrm{C}$ as a function of relative humidity: $\bigcirc 0 \%, 11 \%, \square 23 \%, \square 33 \%, \triangle 59 \%$ studied, the effect of relative humidity on survival remained similar. A relative humidity of about $11 \%$ is considered best to maintain viability during storage. It can also be seen that the viability of cells decreased rapidly at the initial period of storage, while they were fairly stable in the subsequent prolonged period at low and intermediate relative humidities.

The effect of incorporating chemical markers of cell damage in the recovery media of stored cells is presented in Tables 1,2. Storage at 59\% $\mathrm{RH}_{\text {eq }}$ resulted in rapid loss of viability with no survivors being detected after 12 days in both experiments. At the concentration used, salt was shown to be inhibitory to cells immediately following drying. At $0,11 \%$ and $33 \% \mathrm{RH}_{\mathrm{eq}}$ the negative effect of the salt increased with time. Furthermore the inhibitory effect was greater at higher $\mathrm{RH}_{\text {eq }}$. Pyronin $Y$ showed no effect on recovery either immediately after drying or during storage. Recovery media incorporating chloramphenicol showed no effect for all relative humidities tested $(P>0.05)$ (data not shown).

The effect of different gases during storage is presented in Fig. 4 for $0 \%$ relative humidity. An increased oxygen concentration caused an acceleration in cell death. Furthermore, replacement of air with nitrogen, improved cell survival.

Changes in the unsaturated/saturated fatty acid index and cell viability are shown in Fig. $5\left(0 \% \mathrm{RH}_{\mathrm{eq}}\right)$ and Fig. $6\left(11 \% \mathrm{RH}_{\mathrm{eq}}\right)$. Results show that, as cell viabilities decreased, the ratio of unsaturated to saturated fatty acids decreased.

The effect of $\mathrm{RH}_{\mathrm{eq}}$ on the fatty acid profile is shown in Fig. 7. Results show that at high relative humidities lipid oxidation occurs more rapidly.
Table 1 Survival of freeze-dried L. bulgaricus dried at $0,11 \%$, $33 \%$ and $59 \%$ equilibrium relative humidity $\left(\mathrm{RH}_{\text {eq }}\right)$ determined on MRS agar and MRS agar with $6.25 \mathrm{mg} / \mathrm{ml}$ sodium chloride in the recovery medium (MRS agar Man Rogosa Sharpe agar)

\begin{tabular}{|c|c|c|c|c|c|c|c|c|}
\hline \multirow{3}{*}{$\begin{array}{l}\text { Time } \\
\text { (days) }\end{array}$} & \multicolumn{8}{|c|}{ Survival $\left[\log (\right.$ no. surviving cells $\left.) / \mathrm{cfu} \mathrm{m}^{-1}\right]$} \\
\hline & \multicolumn{2}{|c|}{$\mathrm{RH}_{\mathrm{eq}}=0$} & \multicolumn{2}{|c|}{$\mathrm{RH}_{\mathrm{eq}}=11 \%$} & \multicolumn{2}{|c|}{$\mathrm{RH}_{\mathrm{eq}}=33 \%$} & \multicolumn{2}{|c|}{$\mathrm{RH}_{\mathrm{eq}}=59 \%$} \\
\hline & MRS & $\mathrm{MRS}+\mathrm{NaCl}$ & MRS & $\mathrm{MRS}+\mathrm{NaCl}$ & MRS & $\mathrm{MRS}+\mathrm{NaCl}$ & MRS & $\mathrm{MRS}+\mathrm{NaCl}$ \\
\hline 0 & 9.0 & 8.2 & 9.0 & 8.2 & 9.0 & 8.2 & 9.0 & 8.2 \\
\hline 12 & 8.5 & 7.7 & 8.6 & 7.3 & 8.3 & 6.9 & 0 & 0 \\
\hline 30 & 8.4 & 7.3 & 8.3 & 7.4 & 6.9 & 5.4 & - & - \\
\hline 97 & 6.8 & 5.1 & 7.9 & 5.9 & 4.6 & 0 & - & - \\
\hline 132 & 6.4 & 0 & 7.5 & 0 & 3.1 & - & - & - \\
\hline SEM & - & 0.11 & - & 0.14 & - & 0.10 & - & - \\
\hline
\end{tabular}

Table 2 Effect on survival of freeze-dried L. bulgaricus of the incorporation of pyronin $\mathrm{Y} P_{y} Y(5 \mu \mathrm{g} / \mathrm{ml})$ in the recovery medium.

\begin{tabular}{|c|c|c|c|c|c|c|c|c|}
\hline \multirow{3}{*}{$\begin{array}{l}\text { Time } \\
\text { (days) }\end{array}$} & \multicolumn{8}{|c|}{ Survival $\left[\log \left(\right.\right.$ no. surviving cells)/cfu $\left.\mathrm{ml}^{-1}\right]$} \\
\hline & \multicolumn{2}{|c|}{$\mathrm{RH}_{\mathrm{eq}}=0$} & \multicolumn{2}{|c|}{$\mathrm{RH}_{\mathrm{eq}}=11 \%$} & \multicolumn{2}{|c|}{$\mathrm{RH}_{\mathrm{eq}}=33 \%$} & \multicolumn{2}{|c|}{$\mathrm{RH}_{\mathrm{eq}}=59 \%$} \\
\hline & MRS & $\mathrm{MRS}+\mathrm{P}_{y} \mathrm{Y}$ & MRS & $\mathrm{MRS}+\mathrm{P}_{\mathrm{y}} \mathrm{Y}$ & MRS & $\mathrm{MRS}+\mathrm{P}_{y} \mathrm{Y}$ & MRS & $\mathrm{MRS}+\mathrm{P}_{\mathrm{y}} \mathrm{Y}$ \\
\hline 0 & 9.0 & 8.9 & 9.0 & 8.9 & 9.0 & 8.9 & $9.0^{\circ}$ & 8.9 \\
\hline 12 & 8.5 & 8.5 & 8.6 & 8.5 & 8.3 & 8.1 & 0 & 0 \\
\hline 30 & 8.4 & 8.3 & 8.3 & 8.3 & 6.9 & 6.9 & - & - \\
\hline 97 & 6.8 & 6.5 & 7.9 & 7.8 & 4.6 & 4.5 & - & - \\
\hline 132 & 6.4 & 6.0 & 7.5 & 7.3 & 3.1 & 2.5 & - & - \\
\hline SEM & - & 0.10 & - & 0.14 & - & 0.15 & - & - \\
\hline
\end{tabular}




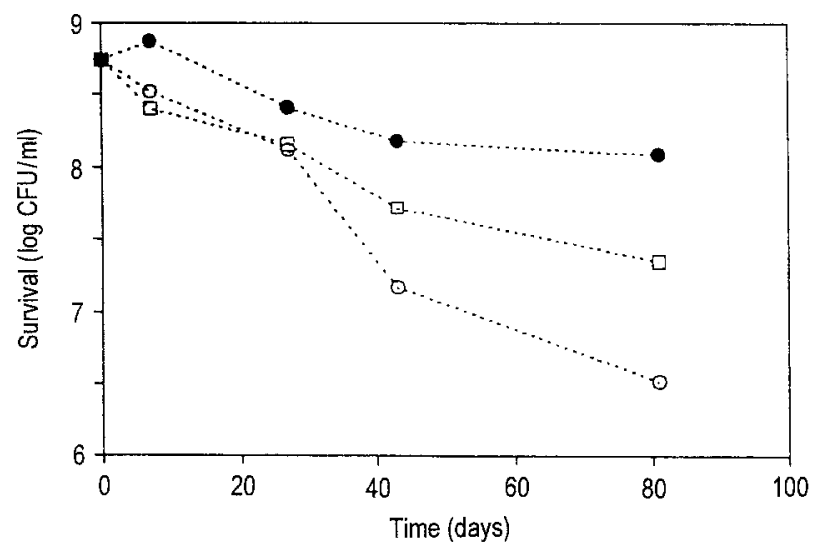

Fig. 4 Survival of freeze-dried L. bulgaricus at $20^{\circ} \mathrm{C}(0 \%$ relative humidity) as a function of the atmosphere: $\bigcirc$ oxygen, nitrogen, $\square$ air

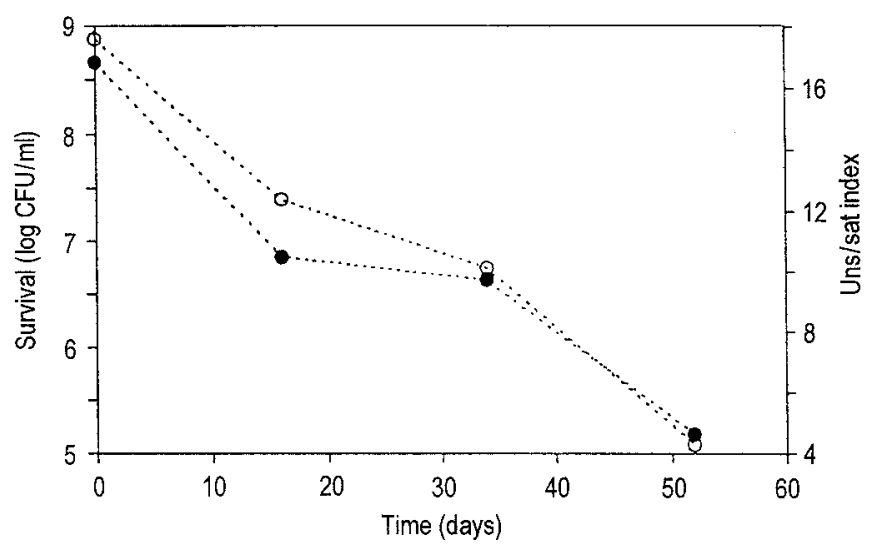

Fig. 5 Comparison of the survival of freeze-dried L. bulgaricus during storage at $0 \%$ relative humidity with the unsaturated/saturated (Uns/sat) index of the membrane fatty acids. $O \log$ (no. surviving $\mathrm{cells}$ )/cfu $\mathrm{ml}^{-1}$ unsaturated/saturated fatty acid index

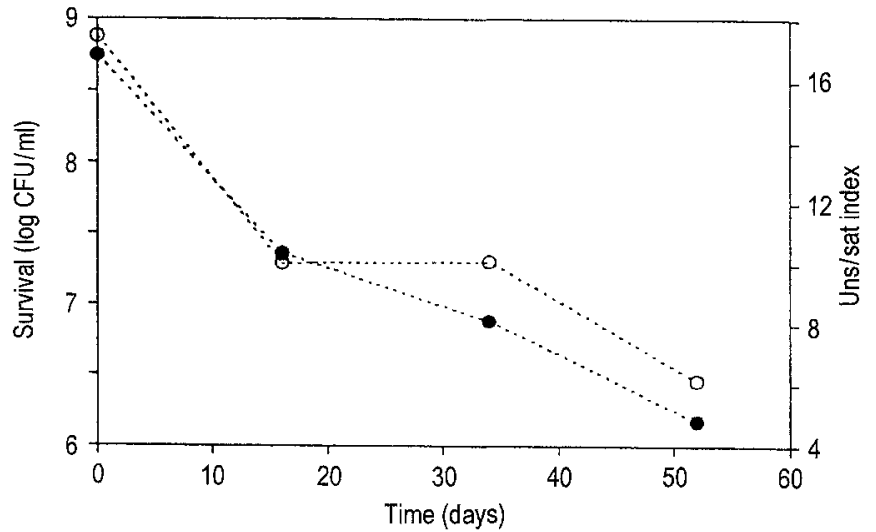

Fig. 6 Comparison of the survival of freeze-dried L. bulgaricus during storage at $11 \%$ relative humidity with the unsaturated/saturated index of the membrane fatty acids. $\bigcirc \mathrm{Log}$ (no. surviving cells)/cfu $\mathrm{ml}^{-1}-$ unsaturated/saturated fatty acid index

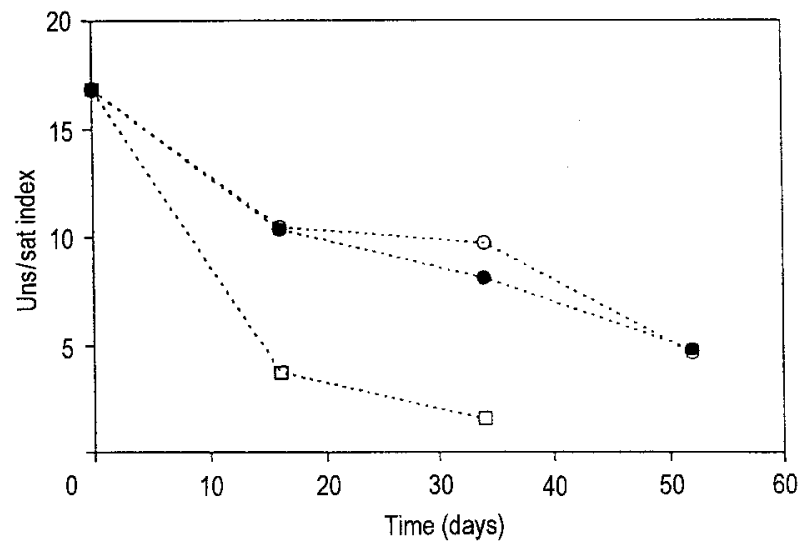

Fig. 7 Variation of the unsaturated/saturated index of the membrane fatty acids during storage of freeze-dried $L$. bulgaricus at the following relative humidities $\left(20^{\circ} \mathrm{C}\right): \bigcirc 0 \%, 11 \%, \square 59 \%$

\section{Discussion}

The purpose of this article was to study the influence of oxygen, humidity and temperature on survival of lyophilized cultures of L. bulgaricus in skim milk and, if possible, to determine a target site(s) responsible for cell death during storage.

The effect of temperature and humidity on bacterial survival are in agreement with previously published results for other microorganisms. The increased survival of lyophilized cultures of lactic acid bacteria at low temperatures has previously been reported by Foster (1962) and Clementi and Rossi (1984). This may be due to a reduction in the rate of fatty acid oxidation. Ishibashi et al. (1985) presented similar results to those reported here in relation to the effect of relative humidity on survival in the presence of air; optimal survival being shown in the intermediate moisture range. Results presented here with recovery in the presence of salt show membrane damage at $0,11 \%, 33 \%$ and $59 \%$ $\mathrm{RH}_{\text {eq }}$ (Sogin and Ordal 1967). The effect, however, at lower $\mathrm{RH}_{\mathrm{eq}}$ values was delayed, occurring only after extended periods of storage. Pyronin $\mathrm{Y}$ and chloramphenicol showed no effect at any $\mathrm{RH}_{\mathrm{eq}}$ values. These results with pyronin $\mathrm{Y}$ are not in agreement with those of some previous authors (Onishi et al. 1977; Asada et al. 1980) who reported DNA damage in bacterial cells as a result of desiccation. The non-linear nature of the curve showing the effect of relative humidity on survival (Fig. 3) can be explained by postulating that more than one mechanism of injury is involved. The reason for the accelerated rate of death at very low water activities could be explained by the damage caused upon the removal of structural water from important cell molecules (Scott 1958).

Results presented here show changes in the lipid composition of the cell membrane with time at different $\mathrm{RH}_{\mathrm{eq}}$ values. The changes in the lipid profile at 0 and $11 \%$ relative humidity were very similar. The decrease 
in the unsaturated/saturated fatty acid index was more pronounced at high $\mathrm{RH}_{\mathrm{eq}}$. High water activities seem to accelerate oxidation by increasing mobilization of components that are made non-reactive at low water activities by being trapped or "encapsulated" within a matrix (Karel 1980).

Changing the gas composition for storage at $0 \%$ $\mathrm{RH}_{\text {eq }}$ after drying affected survival during the later phases of the trial. Storage under vacuum or inert gases has previously been reported to improve bacterial survival during storage (Yang and Sandine 1979). The initial similarity of the three curves points to a common mechanism causing cell death. Other authors working with a variety of cells have pointed to the importance of the presence of preformed free radicals, which are involved in causing cell death (Anonymous 1961; Carlsson et al. 1978; Halliwell and Gutteridge 1984; Mackey and Seymour 1987). A possible explanation is that, in the early periods of storage, oxidation reactions may not be dependent on the presence or absence of free molecular oxygen but on the presence of reactive free radicals in the suspending matrix.

The consequences of oxidation can be very important to the cell. A specific event that has been linked to loss of membrane structure and function as a consequence of lipid peroxidation in mitochondrial membranes incubated in the presence of ascorbate or cysteine, is the loss of some enzyme activities, among them that of ATPases (Santiago et al. 1973). Uncontrolled peroxidation of biomembranes can lead to profound effects on membrane structure and function and may be sufficient to cause cell death (Slater 1984).

The results presented here demonstrate the importance that must be attributed to the control of temperature, atmosphere and residual water activity of dried cultures in order to optimize survival.

\section{References}

Anonymous (1961) The drying operation. The accelerated freezedrying (AFD) method of food preservation. Ministry of Agriculture, Fisheries and Food, Pinner, UK

Asada S, Takano M, Shibaski I (1980) Methods for prevention of breakage of DNA strands and mutation induction caused by cell drying in Escherichia coli. Hakkokoguko Kaishi 58:423-430

Carlsson J, Nyberg G, Wrethén J (1978) Hydrogen peroxide and superoxide radical formation in anaerobic broth exposed to atmospheric oxygen. Appl Environ Microbiol 36:223-229
Champagne CP, Detournay H, Hardy MJ (1991) Effect of medium on growth and subsequent survival, after freeze-drying, of Lactobacillus delbrueckii subsp. bulgaricus. J Ind Microbiol 7:147-150

Clementi F, Rossi J (1984) Effect of drying and storage conditions on survival of Leuconostoc oenos. Am J Enol Vitic 35:183-186

Couture R, Gagné D (1991) Effect de divers additifs sur la survie à la lyophilization de Lactococcus lactis. Can Inst Sci Technol J 24:224-227

De Man JCA, Rogosa M, Sharpe ME (1964) Medium for the cultivation of lactobacilli. J Appl Bacteriol 23:130-136

Foster EM (1962) Culture preservation. J Dairy Sci 45:1290-1294

Girotti AW, Thomas JP (1984) Damaging effects of oxygen radicals on resealed erythrocyte ghots. J Biol Chem 259:1744

Halliwell B, Gutteridge JMC (1984) Oxygen toxicity, oxygen radicals, transition metals and disease. Biochem J 219:1-14

Ishibashi N, Tatematsu T, Shimamura S, Tomita M, Okonogi S (1985) Effect of water activity on the viability of freeze-dried bifidobacteria and lactic acid bacteria. Refrig Sci Technol 1:227-232

Israeli E, Kohn A (1972) Protection of lyophilized Escherichia coli from oxygen by colicin E1 treatment. FEBS Lett 26:323-326

Karel M (1980) Lipid oxidation, secondary reactions and water activity of foods. In: Simic MG, Karel M (eds) Autoxidation in food and biological systems. Plenum press, New York

Lion MB, (1963) Quantitative aspects of protection of freeze-dried Escherichia coli against the toxic effect of oxygen. J Gen Microbiol 32:321

Mackey BM, Seymour DA (1987) The effect of catalase on recovery of heat-injured DNA repair mutants of Escherichia coli. $\mathbf{J}$ Gen Microbiol 21:119-122

Miles AA, Misra SS (1936) The estimation of the bactericidal power of blood. J Hyg (Cambridge) 38:732-749

Morich T (1974) Preservation of lactic acid bacteria by freeze-drying Jpn Agric Res Q 8:171

Naylor HB, Smith PA (1946) Factors affecting the viability of serratia marcescens during dehydration and storage. J Bacteriol $52: 565$

Onishi T, Tanaka Y, Yoh M, Takeda Y, Miwatani T (1977) Deoxyribonucleic acid strand breaks during freeze-drying and their repair in Escherichia coli. J Bacteriol 130:620-628

Pryor WA (1971) Free radical Chem Eng News 49:34

Rozès N, Garbay S, Denayrolles M, Lonvaud-Funel A (1993) A rapid method for the determination of bacterial fatty acid composition. Lett Appl Microbiol 17:26-131

Santiago E, López-Moratalla N, Segovia JL (1973) Correlation between losses of mitochondrial ATPase activity and cardiolipin degradation. Biochem Biophys Res Commun 53:439-445

Scott WJ (1958) The effect of residual water on the survival of dried bacteria during storage. J Gen Microbiol 19:624-633

Sinskey AJ (1971) Current status of injury in freeze-dried microorganisms. J Milk Food Technol 34:551-552

Slater TF (1984) Free-radical mechanisms in tissue injury. Biochem $\mathrm{J}$ (review article) $222: 1-15$

Sogin SJ, Ordal ZJ (1967) Regeneration of ribosomes and ribosomal ribonucleic acid during repair of thermal injury to Staphylococcus aureus. J Bacteriol 94:1082-1087

Yang NL, Sandine WE (1979) Acid-producing activity of lyophilized lactic streptococcal cheese starter concentrates. J Dairy Sci 62:908-915 